\title{
MONITORING OF THE PRODUCTION PROCESSING IN A METALLURGICAL COMPANY USING FMEA METHOD
}

\begin{abstract}
The possibility of use of Failure Mode and Effect Analysis methods is connected with continuous quality improvement of production processes in companies. Interdependence of the quality research methods and production process's requirements have been taken into account. FMEA method is the analysis aimed at the disclosure and elimination of potential weaknesses of the process, that is the variants that may cause defects during its implementation. The example of implementing Failure Mode and Effect Analysis in polish companies have been presented.
\end{abstract}

Keywords: Quality management; Failure Mode and Effect Analysis; Number of Risk, The product life cycle

\section{Introduction}

Building the success of the organisation from the perspective of quality is a crucial factor for managing a manufacturing company. Nowadays, achieving high quality products and simultaneously meeting customer requirements are the elements of strategic activities of companies. In order to achieve a high position on the market, both management staff and all employees should continually strive for improvement of the products manufactured and a reduction of potential defectiveness, as well as the number of complaints [1-3].

Innovation, variability, development of information technologies, prevention from errors and deficiencies in processes, and their optimisation influence the increasingly common awareness that the quality of the final product is not only the result of the production process exclusively, but it is a result of many processes and activities related to the formation and possession of the product. Taking into account the customer benefit and ruthless market laws, application of more and more developed systems for monitoring and controlling quality of the life cycle of products is a necessary requirement for a modern company [1].

The use by manufacturing companies of quality evaluation methods and tools, including in particular the FMEA method, allows for the analysis of the quality of the design, the process or the finished product.

\section{Methodology of the procedure based on the quality control and the FMEA method.}

\section{Essence of quality control in a manufacturing company}

Bearing in mind the recommendations of the PN-EN ISO 9000:2006 standard, the quality of the product refers not only to its manufacturing, to meet the needs and expectations of a customer, but also to its implementation, sale and recycling, and "the quality of the product is shaped and perceived throughout its whole life cycle" $[1,4]$. From the point of view of the manufacturing company, the correct identification of the product life cycle is necessary for the tasks that go far beyond the production phase. Awareness of the corporate responsibility for the quality of the final product has an influence on the method of monitoring and controlling the processes in the pre-production, production, and post-production area on the basis of quality [5-7].

Currently, the perception of quality from the angle of quality control and the use of methods, techniques, and tools of quality is essential. The quality control is therefore a "system" related to planning and coordinating activities in the field of maintaining and improving the quality at individual stages of design and organisation of the production process, while maintaining the optimal level of investment and fully meeting the customer requirements. It is worth stressing that at each stage of creation of the product team work, knowledge, and flexibility of information transmission, that are the determinants of intangible resources of the company, are very important aspects $[1,6,8,9]$. 
During the planning and design phase, such tools as brainstorming, Analytical Selection of Construction Materials, and QFD (Quality Function Deployment) method, can be used in transforming customer expectations into technical requirements and establishing priorities, and the FMEA method can then be used for the purposes of evaluation of potential problems in relation to the particular project, saving a lot of time during the product construction through the elimination of the incorrect approach. At the stage of the product construction, the aforementioned FMEA, as well as statistical tolerances, reliability techniques, regressions, modelling, and simulations can be used. These methods use the creative potential of employees since they are based on the team work. They enable early responding, provide orientation in the size of threats. The QFD action includes the entire process of gathering information, determining the structure and giving priority to individual problems, it causes incredible improvement in understanding the product design in conjunction with the FMEA of the design/construction. Application of the Statistical Acceptance Control and the SPC (Statistical Process Control) during the implementation of the manufacturing process may allow for the removal of defective products on the basis of statistical analysis of selected samples, another use of the FMEA of the process affects full understanding of operations during the manufacturing process. At the life stage of the production cycle after sale the trend analysis, an analysis of the FMEA of the product will help the company identify recurring negative phenomena that should be corrected. Defining weaknesses of the product life cycle, their analysis and implementation of corrective actions is a guarantee of good practice in the implementation of the processes and offering customers the high quality product $[1,2]$.

\section{FMEA method-assumptions, types, procedure, benefits, advantages and disadvantages}

The FMEA is a preventive method, in which a group of appointed individuals analyses the structures of the product, as well as its manufacturing process in order to identify all locations and areas, in which potential errors, defects, and problems may arise, and then determines actions aimed at eliminating those errors. It is a versatile method of analysis, which can be used in various industries, in particular in the automotive, machinery and steel industries [1,4,6-10].

This method was founded in the 1960s in NASA during the implementation of the "Apollo" space programme. In its first assumptions the FMEA was used for the preparation of complex manufacturing processes and very responsible products used in aeronautics, nuclear technology, and the aviation industry. The appropriate approach to the analysis of the FMEA method of the design, process, and product while reducing production costs was decisive for its popularisation in other industries. Since 1994, the FMEA has been a mandatory analysis carried out in accordance with requirements of the ISO/TS 16949 standard and new standard IATF $[2,6,8]$. The Failure Mode and Effect Analysis comes down to identifying potential errors and eliminating them.
Details of the analysis were described in PN-EN 60812 standard. The use of the FMEA of the process is recommended at the initial phase of the process design, before launching production, and during series production in order to improve the processes that are unstable in nature or do not allow for achieving the required quality and performance. Before the application of the analysis you should appoint a team of employees responsible for the development and monitoring. It should consist of employees from all the levels of the organisation hierarchy. After training the team, you should proceed to the stage of defining aspects of the FMEA in a reliable, true, and objective manner $[1,8,10,11]$.

There are two types of the FMEA analysis: product/construction/project; process. The product/construction FMEA is carried out during the design work in order to obtain information about its strengths and weaknesses. The analyses show that as much as $75 \%$ of errors arise during the design phase, therefore, as much as $75 \%$ of errors can be avoided before product plan goes to production. As a result, even prior to the construction works you can make changes in the manufacturing concept of the product. Defects detected during this type of the FMEA analysis may include: the range of features that the product must have, reliability of the product during its entire operation, safe use of the product, ease of use and repair, manufacturability of the construction (or a lack thereof), costs associated with the operation of the product. It is recommended to apply this type of analysis where the new products are marketed (both the product as a whole and the application of the new parts and components only, new materials or changes in the manufacturing technology), the existing products are modified or their new features are discovered without modifications. The FMEA of the product is also applied where hazards in connection with use are already detected during the operation, or the product is designed to work in harsh conditions. The FMEA of the process is carried out during the design or improvement of the process - the aim is to detect any factors that through its influence would hinder the fulfilment of the requirements contained in the documentation. Defects detected during this type of the FMEA analysis may include: methods of action and procedure in specific situations, correctness of the process parameters, proper functioning of the control devices, correctness of functioning of the machinery and equipment, impact of the environment on the process, all these factors at the same time. When determining the indicators probability of defects $(\mathrm{P})$, importance of defects $(\mathrm{Z})$, traceability of defects $(\mathrm{W})$ and the risk priority number $\mathrm{R}$, you can use the instructions included in TABLE 1 [1,7,8-11].

\section{Example of application of the FMEA method in a selected process of a metallurgical company}

The main qualitative objective of the metallurgical company that implemented the Quality Management System compliant with ISO 9001:2015 is the continuous improvement of products and modernisation of technology, and thus optimisation of the costs while meeting customer requirements. 
The indicator of estimation of number of risk R [11]

\begin{tabular}{|c|c|c|c|c|c|}
\hline \multicolumn{6}{|c|}{ The Indicators } \\
\hline \multicolumn{2}{|c|}{ Probability of Defects (P) } & \multicolumn{2}{|c|}{ Importance of Defects (Z) } & \multicolumn{2}{|c|}{ Traceability of Defects (W) } \\
\hline Failure mode occurrence & Rating & Severity & Ranking & Detection & Ranking \\
\hline Remote & 1 & None & 1 & Almost certain & 1 \\
\hline Low & $2-3$ & Very minor & 2 & Very high & 2 \\
\hline Moderate & $4-6$ & Minor & 3 & High & 3 \\
\hline High & $7-8$ & Very low & 4 & Moderately high & 4 \\
\hline Very high & $9-10$ & Low & 5 & Moderate & 5 \\
\hline & & Moderate & 6 & Low & 6 \\
\hline & & High & 7 & Very low & 7 \\
\hline & & Very high & 7 & Remote & 8 \\
\hline & & Hazardous with warning & 9 & Very Remote & 9 \\
\hline & & Hazardous without warning & 10 & Absolutely uncertain & 10 \\
\hline
\end{tabular}

In the company under consideration it was found that there was a need to conduct the FMEA Method to examine the process of launching production of a new product, a seamless tube $\varnothing 65 \times 3.1 \times 1056$ of steel grade G335 according to PN79/H-74244, at the Tube Works Department. This department is engaged in the production of seamless tubes mainly for the construction of the chemical industry equipment. Typical applications include: heat exchangers, acid tanks for the paint industry and pharmaceutical industry equipment, pump parts, and components of machines operating in environments with high risk of intergranular corrosion. The material for the production was provided with a certificate of acceptance by the manufacturer. The technology of manufacturing of steel tubes with dimensions of $\varnothing 65 \times 3.1 \times 1056$ of steel grade G335 was presented in TABLE 2.

Technology of manufacturing of steel tubes with dimensions of $\varnothing 65 \times 3.1 \times 1056$ of steel grade G335

\begin{tabular}{|c|c|}
\hline Name of ohe operation & Description \\
\hline 1 & 2 \\
\hline Sharpening of ends & $\begin{array}{l}\text { sharpening of ends of the charging tube is carried out on a tube pointer. The purpose of this operation is to prepare } \\
\text { the tube for the drawing operations. Owing to the sharpened end of the tube, it is possible to start the process of } \\
\text { drawing. }\end{array}$ \\
\hline Cutting into two parts & $\begin{array}{l}\text { Cutting the charging tube into two parts after prior sharpening of its ends is carried out with the use of an abrasive } \\
\text { saw. This results in two pipes of a length equal to half the length of the charging tube. One end of the tube is } \\
\text { sharpened and the other is blunt. }\end{array}$ \\
\hline Annealing & $\begin{array}{l}\text { The operation of annealing of the tubes is a preliminary heat treatment process. Its purpose is to soften the material } \\
\text { and obtain an appropriate output structure enabling the cold drawing of the tubes. This operation is carried out in the } \\
\text { roller hearth furnace located in the Tube Works Department. Technical conditions for annealing of the tubes must } \\
\text { be strictly observed, otherwise the result is the occurrence of defects during the drawing operations of tubes. In the } \\
\text { case of the process examined the tubes should be annealed at } 800^{\circ} \mathrm{C} \text {. }\end{array}$ \\
\hline $\begin{array}{l}\text { Pickling } \\
\text { and preparation of } \\
\text { surface }\end{array}$ & $\begin{array}{l}\text { Operation of pickling and preparation of the tube surface is performed in the pickling plant in the Tube Works } \\
\text { Department. Its purpose is to ensure such characteristics of the tube surface as to allow optimal flow of the } \\
\text { drawing process. It is a complex operation consisting of the following steps: pickling hot-rolled tubes; applying the } \\
\text { lubricating ground (phosphating). }\end{array}$ \\
\hline First draught & $\begin{array}{l}\text { cold drawing of the tubes is characterised by shaping dimensions with a drawing die. This operation is carried } \\
\text { out on the drawing machines, among which the following can be distinguished: drawing devices with a specific } \\
\text { drawing power together with a drive unit, deforming tools including drawing dies and mandrels. Due to the nature } \\
\text { of the deformation process, it is very important to reduce the friction coefficient during drawing. In the case of the } \\
\text { tube examined, drawing on a short mandrel has been applied. A short mandrel mounted rigidly on a rod fixed to the } \\
\text { drawing machine was inserted into the tube. This process should be performed with the use of a very good lubricant, } \\
\text { as the lubricant applied determines the smoothness of the surface. The first draught is intended to change the tube } \\
\text { dimensions: the outer diameter from } 76.1 \mathrm{~mm} \text { to } 70 \mathrm{~mm} \text { and the wall thickness from } 4.5 \mathrm{~mm} \text { to } 4.00 \mathrm{~mm} \text {. At the } \\
\text { same time the tubes increase their length. }\end{array}$ \\
\hline Surface preparation & $\begin{array}{l}\text { this operation aims at the re-preparation of the tube surface for drawing, that is the application of lubricating ground } \\
\text { (phosphating). This operation consists of phosphating, rinsing, and neutralising in the emulsion. }\end{array}$ \\
\hline
\end{tabular}




\begin{tabular}{|c|l|}
\hline 1 & \multicolumn{1}{|c|}{ 2 } \\
\hline Second draught & $\begin{array}{l}\text { the outer diameter of the tube changes from } 70.00 \mathrm{~mm} \text { to } 64.9 \mathrm{~mm} \text { and the wall thickness changes from } 4.00 \mathrm{~mm} \text { to } \\
3.2 \mathrm{~mm} \text {. The metal is strengthened and requires annealing. }\end{array}$ \\
\hline Heat treatment & $\begin{array}{l}\text { normalising was applied in order to maintain the uniform fine-grained metal structure and achieve the related } \\
\text { improvement of the mechanical properties. In order to avoid chemical changes on the surface of heat-treated tubes, } \\
\text { use the protective atmospheres. In order to obtain such properties of the tubes, inspections of furnace conditions } \\
\text { (temperature, movement speed, tube surface quality) are carried out regularly in accordance with the Inspection } \\
\text { Cycle Sheet of the heat treatment in the roller hearth furnace, the annealing process parameters are recorded } \\
\text { automatically. }\end{array}$ \\
\hline Straightening of tubes & $\begin{array}{l}\text { preliminary straightening is carried out on the tubes with high curvature resulting from the specific technological } \\
\text { processes. Therefore, these tubes are not straightened on the roller straightening machines. Decisions about the } \\
\text { preliminary straightening are made by the shift master through the evaluation of the degree of curvature and the } \\
\text { condition of the tubes. The final straightening operation is carried out on the roller straightening machines. These } \\
\text { straightening machines are used only for straightening the tubes with circular cross-section and differ in terms of } \\
\text { the way of transmitting the drive and setting of the straightening rolls. }\end{array}$ \\
\hline Finishing of the tubes & $\begin{array}{l}\text { the operation of finishing the tubes consists of the following procedures: cutting the tubes to the precise length of } \\
\text { 1056 mm, deburring, grinding. In the drawn tubes the ends are cut off from both sides. At the front of the tube the } \\
\text { deformed portions are separated with pliers in the drawing operation, at the rear - due to inadequate dimensional } \\
\text { parameters of the tube end. Deburring, i.e. milling of the tube ends, is aimed at removing protruding sharp burrs on } \\
\text { both outer and inner surfaces after the cutting procedure. Grinding of the outer surface of the tubes is used mainly } \\
\text { for removing the occurring surface defects or upon customer's request. }\end{array}$ \\
\hline
\end{tabular}

In other words, the purpose of application of the FMEA method in the present case is the analysis aimed at the disclosure and elimination of potential weaknesses of the process, that is the variants that may cause defects during its implementation.

It has been agreed that the three groups of incompatibilities, which are most often used in the manufacturing of the tubes shall be considered, and these include: the surface defects, the shape defects, and the material defects. Also locations of formation of the defects and incompatibilities have been determined: input material defects, defects resulting from the heat treatment process of tubes, defects resulting from the tube surface preparation process, defects resulting from the drawing of tubes, defects occurring in the finishing room, defects resulting from the transport of tubes, defects occurring in the warehouse of tubes.
Therefore, seven locations of the possible formation of the three types of defects have been examined. 21 points have been evaluated in terms of: probability of defects $(P)$, importance of defects $(Z)$, traceability of defects $(W)$. Subsequently, the risk priority number $(\mathrm{R})$ was calculated.

The FMEA analysis began with the evaluation of occurrences of the defects depending on the location of their occurrence, and subsequently the importance of the defects in each point of their formation, as well as the traceability of the defects in each point of their formation were evaluated. Results of individual action steps for the present case of the selected metallurgical product, i.e. the seamless tube, can be found in TABLE 3.

During the analysis of the FMEA method sheet data, it was found that there are two ways to reduce the risk number: by re-

Number of risk at the beginning of FMEA analysis the technology of manufacturing of steel tubes

\begin{tabular}{|c|c|c|c|c|c|c|c|c|c|}
\hline & & & \multicolumn{7}{|c|}{ Location of formation of defects and incompatibilities } \\
\hline & & & $\begin{array}{c}\text { Input } \\
\text { material }\end{array}$ & $\begin{array}{c}\text { Heat } \\
\text { treatment } \\
\text { process }\end{array}$ & $\begin{array}{c}\text { Surface } \\
\text { preparation } \\
\text { process }\end{array}$ & $\begin{array}{l}\text { Drawing of } \\
\text { tubes }\end{array}$ & $\begin{array}{l}\text { The finishing } \\
\text { room of tubes }\end{array}$ & $\begin{array}{c}\text { Transport of } \\
\text { tubes }\end{array}$ & $\begin{array}{l}\text { Warehouse of } \\
\text { tubes }\end{array}$ \\
\hline \multirow{12}{*}{ 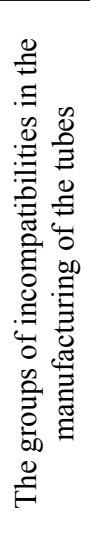 } & \multirow{4}{*}{ 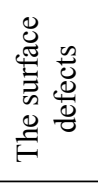 } & $\mathbf{P}$ & 5 & 2 & 8 & 3 & 4 & 6 & 1 \\
\hline & & $\mathbf{Z}$ & 2 & 6 & 6 & 6 & 6 & 2 & 2 \\
\hline & & $\mathbf{W}$ & 4 & 1 & 1 & 1 & 1 & 1 & 1 \\
\hline & & $\boldsymbol{R}$ & 40 & 12 & $\underline{48}$ & 18 & 24 & 12 & 2 \\
\hline & \multirow{4}{*}{ 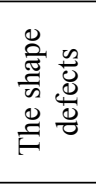 } & $\mathbf{P}$ & 4 & 1 & 3 & 7 & 5 & 4 & 1 \\
\hline & & $\mathbf{Z}$ & 2 & 2 & 2 & 10 & 10 & 2 & 2 \\
\hline & & $\mathbf{W}$ & 1 & 1 & 5 & 3 & 3 & 3 & 1 \\
\hline & & $\boldsymbol{R}$ & 8 & 2 & 30 & $\underline{210}$ & $\underline{150}$ & 24 & 2 \\
\hline & \multirow{4}{*}{ 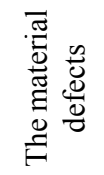 } & $\mathbf{P}$ & 2 & 3 & 1 & 1 & 1 & 1 & 1 \\
\hline & & $\mathbf{Z}$ & 10 & 10 & 10 & 10 & 10 & 10 & 10 \\
\hline & & $\mathbf{W}$ & 4 & 3 & 1 & 1 & 1 & 1 & 1 \\
\hline & & $\boldsymbol{R}$ & $\underline{80}$ & $\underline{150}$ & 10 & 10 & 10 & 10 & 10 \\
\hline
\end{tabular}


ducing the possibility of occurrence of defects, by increasing the traceability of defects occurring. At the next stage, all the causes of defects described above, the task of which is to achieve the best results, were checked in terms of specific corrective actions. It was recognised that a critical priority risk number amounted to the value of 45 . The order of corrective actions implemented was determined on the basis of the risk numbers. The highest number occurs in the case of shapes resulting from the drawing of the tubes. To improve this condition the causes of these defects were analysed. The main causes are improper technical condition of the drawing tools and wrong configuration of the drawing tools. Therefore, the following measures were taken: introduction of records of the drawing tools in order to determine their working time and in order not to use them after the expiry of the intended operation time, introduction of the measuring instruments for inspection of the drawing tools, introduction of the devices for the regeneration of dies and plugs. As a result of these corrective measures, the number of occurrences of the shape defects arising during the drawing of tubes was reduced. An analysis of the traceability of the shape defects arising during the drawing of tubes has also been carried out. As a result, after the development of appropriate procedures for carrying out operations on the trial batch, there was an improvement. This resulted in a new risk number for the shape defects arising during the drawing of tubes, which amounted to 40 (previous result 210). Material defects occurring as a result of the heat treatment of tubes: inappropriate softening of the material and inadequate output structure were the next point subjected to the analysis. These defects were caused by a maladjustment of the tube annealing time to the type of materials and the tube dimensions. Corrective measures include random checking of correctness of the heat treatment conducted. After increasing the frequency of testing mechanical properties of tubes, traceability of material defects during the heat treatment was awarded 2 points. The risk number for the present situation amounted to 40 (previous value 150). The next point subjected to the analysis was the shape defect formed in the tube finishing room. The most common shape defects in the finishing room were inadequate outer diameters of the tubes and cuts, that is all dents, damages to the pipe profile. Therefore, the following measures were taken: application of the liner in the tube racks in order to absorb shocks of falling tubes, extension of responsibility for the straightening quality on the foreman. An analysis was also conducted on the detection of the shape defects during the tube finishing operations. The decision was made to introduce the control cards to the straightening station. The risk number amounted to 30 (previously 150). Material defects of the charge have also been analysed. The most important disadvantage of the charge was the lack of information about the tensile strength, therefore, it was decided to introduce the obligation to provide the charge of that value by the supplier. As a result, the risk number amounted to 20 . Subsequently, the defects of the tube surface occurring as a result of the operations of the tube surface preparation were analysed. The defects of this type include: stains, pits. The decision was made to upgrade the technology of pickling and preparation of tube surface for drawing to reduce the possibility of failure to follow the process parameters. The risk number amounted to 24 . The values presented in TABLE 4 were corrected.

The use of the FMEA method in this example confirmed its usefulness. It enabled to determine which of the potential defects and what causes were the most significant, what the basis for the determination of the priority of corrective actions taken was. In the case of the Seamless Tubes Department, it turned out that such priorities are the measures taken in order to reduce the occurrence of the shape defects arising during the drawing of tubes and the finishing operation. It was also important to minimise the material defects of the tubes resulting from the inaccurate heat treatment.

TABLE 4

Number of risk after FMEA analysis the technology of manufacturing of steel tubes

\begin{tabular}{|c|c|c|c|c|c|c|c|c|c|}
\hline & & & \multicolumn{7}{|c|}{ Location of formation of defects and incompatibilities } \\
\hline & & & $\begin{array}{c}\text { Input } \\
\text { material }\end{array}$ & $\begin{array}{c}\text { Heat } \\
\text { treatment } \\
\text { process }\end{array}$ & $\begin{array}{c}\text { Surface } \\
\text { preparation } \\
\text { process }\end{array}$ & $\begin{array}{l}\text { Drawing of } \\
\text { tubes }\end{array}$ & $\begin{array}{l}\text { The finishing } \\
\text { room of tubes }\end{array}$ & $\begin{array}{c}\text { Transport of } \\
\text { tubes }\end{array}$ & $\begin{array}{c}\text { Warehouse of } \\
\text { tubes }\end{array}$ \\
\hline \multirow{12}{*}{ 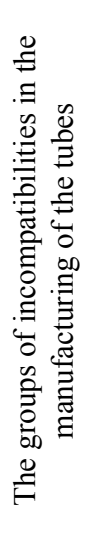 } & \multirow{4}{*}{ 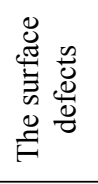 } & $\mathbf{P}$ & 5 & 2 & 4 & 3 & 4 & 6 & 1 \\
\hline & & $\mathbf{Z}$ & 2 & 6 & 6 & 6 & 6 & 2 & 2 \\
\hline & & $\mathbf{W}$ & 4 & 1 & 1 & 1 & 1 & 1 & 1 \\
\hline & & $\boldsymbol{R}$ & 40 & 12 & $\underline{24}$ & 18 & 24 & 12 & 2 \\
\hline & \multirow{4}{*}{ 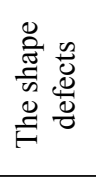 } & $\mathbf{P}$ & 4 & 1 & 3 & 2 & 3 & 4 & 1 \\
\hline & & $\mathbf{Z}$ & 2 & 2 & 2 & 10 & 10 & 2 & 2 \\
\hline & & $\mathbf{W}$ & 1 & 1 & 5 & 2 & 1 & 3 & 1 \\
\hline & & $\boldsymbol{R}$ & 8 & 2 & 30 & $\underline{40}$ & $\underline{30}$ & 24 & 2 \\
\hline & \multirow{4}{*}{ 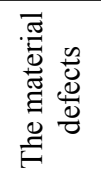 } & $\mathbf{P}$ & 2 & 2 & 1 & 1 & 1 & 1 & 1 \\
\hline & & $\mathbf{Z}$ & 10 & 10 & 10 & 10 & 10 & 10 & 10 \\
\hline & & $\mathbf{W}$ & 1 & 2 & 1 & 1 & 1 & 1 & 1 \\
\hline & & $\boldsymbol{R}$ & $\underline{20}$ & $\underline{40}$ & 10 & 10 & 10 & 10 & 10 \\
\hline
\end{tabular}




\section{Summary}

The main objective of the FMEA method in the analysed case is to improve the quality of the designed product with an emphasis on the production process. Therefore, we can achieve the following results: identification of the influence of defects on the product, determination of risk reduction measures; verification or completion of the specification of requirements for the process; saving time and costs through the identification of potential hazards. The FMEA method applied at the early stages is used for design verification, and, in particular, for the verification of the requirements of software modules, choosing the programming language, tools or techniques for testing. Used at the later stages, it can certify the validity of the choices made. Information grows gradually along with the analysis in the subsequent stages of the life cycle of the system. The advantage of the FMEA method is that in special cases it is possible to apply it only for elements considered as critical. In the case of larger systems, it is recommended to carry it out for all their elements.

\section{Acknowledgements}

This work was supported by the Ministry of Science and Higher Education of Poland as the statutory financial grant of the Faculty of Mechanical Engineering, Silesian University of Technology

\section{REFERENCES}

[1] M. Dudek-Burlikowska, Application of FMEA method in enterprise focused on quality, Journal of Achievements in Materials and Manufacturing Engineering 45/1, 89-102 (2011).

[2] M. Dudek-Burlikowska, Zarządzanie procesami i ich ciagłe doskonalenie z wykorzystaniem narzędzi i technik jakości w wybranym przedsiębiorstwie, w: E. Skrzypek Sposoby osiagania doskonałości organizacji w warunkach zmienności otoczenia. Wyzwania teorii i praktyki. T. 1., UMCS, Lublin, s. 169-177 (2006).

[3] S. Tkaczyk, Inżynieria jakości, a inżynieria materiałowa. ORGMASZ. Warszawa (2000).

[4] PN-EN ISO 9000:2006: Systemy zarządzania jakością - Podstawy i terminologia, PKN 2006.

[5] I. Durlik, Inżynieria zarządzania: strategia i projektowanie systemów produkcyjnych. Cz. 2, Agencja Wydawnicza Placet, Warszawa (1999).

[6] J. Łunarski, Zarządzanie jakością: standardy i zasady, WNT, Warszawa (2008).

[7] M. Dudek-Burlikowska, Aspects of improving the organization directed to the quality, Archives of Materials Science and Engineering 43, 2, 101-108 (2010).

[8] A. Hamrol, Zarządzanie jakością z przykładami, PWN, Warszawa (2005).

[9] K. Szczepańska, Metody i techniki TQM, Oficyna Wydawnicza Politechniki Warszawskiej, Warszawa (2009).

[10] J. Gawlik, Metody i narzędzia w analizie jakości wyrobów, Wydawnictwo Politechniki Krakowskiej, Kraków (2008).

[11] IEC 60812:2006, Analysis techniques for system reliability Procedure for failure mode and effects analysis (FMEA), 2006 CENELEC 